\title{
Identification of a Gene Encoding Adenylate Kinase Involved in Antifungal Activity Expression of the Biocontrol Strain Burkholderia pyrrocinia CH-67
}

\author{
Kwang Youll Lee', Hyun-Gi Kong ${ }^{2}$ and Seon-Woo Lee ${ }^{2 *}$ \\ ${ }^{\prime}$ Advanced Radiation Technology Institute, Korea Atomic Energy Research Institute, Jeongeup 580-185, Korea \\ ${ }^{2}$ Department of Applied Biology, Dong-A University, Busan 604-714, Korea
}

(Received on August 16, 2012; Revised on September 25, 2012; Accepted on September 25, 2012)

\begin{abstract}
Burkholderia pyrrocinia $\mathrm{CH}-67$ is a biocontrol bacterium with strong antifungal activity against several plant pathogenic fungi. Transposon mutagenesis was performed to identify the genes responsible for the antifungal activity of $B$. pyrrocinia $\mathrm{CH}-67$. Of the 2,500 mutants tested using the Fulvia fulva spore screening method, a mutant deficient in antifungal activity, M208, was selected. DNA sequence analysis of the transposon-inserted region revealed that a gene encoding an adenylate kinase-related kinase was disrupted in M208. Antifungal activity was restored in $\mathrm{M208}$ when a full-length adenylate kinase gene with its promoter was introduced in trans. The deduced amino acid sequence of adenylate kinase from $\mathrm{CH}-67$ was $80 \%$ identical to that of $B$. cenocepacia MCO-3. Adenosine diphosphate supplementation or high levels of adenosine triphosphate and adenosine monophosphate together restored antifungal activity in M208, suggesting that adenylate kinase of B. pyrrocinia CH-67 is involved in antifungal activity expression.
\end{abstract}

Keywords : adenylate kinase, antifungal activity, Burkholderia pyrrocinia, Fulvia fulva

Biological control of plant diseases is a good alternative strategy for plant fungal disease management. Several plant fungal diseases cause extensive crop damage worldwide, although various chemical fungicides have been developed to control the diseases (Farr et al., 1989). While fungicides are effective in controlling plant diseases, environmental concerns and the development of resistance in the target fungal pathogens have reduced the utility of chemical fungicides. In addition, the demand for organic food is gradually increasing. For these reasons, biological control has received much attention (Andrews et al., 1992; Becker and Schwinn, 1993; Handelsman and Stabb, 1996). Several studies have reported the effective control of fungal disease

\footnotetext{
*Corresponding author.

Phone) +82-51-200-7551, FAX) +82-51-200-7505

E-mail)seonlee@dau.ac.kr
}

in the greenhouse using various microorganisms (Asaka and Shoda, 1996; Mao et al., 1998; McLoughlin et al., 1992; Roberts et al., 2005). The microorganisms include fluorescent pseudomonads that produce antibiotics, such as phenazines (Mavrodi et al., 2006), 2,4-diacetylphloroglucinol (Fenton et al., 1992; Keel et al., 1992), pyrrolnitrin (ElBanna and Winkelmann, 1998; Hill et al., 1994), pyoluteorin (Howell and Stipanovic, 1980; Kraus and Loper, 1995), and siderophores (Dowling and O'Gara, 1994). Bacillus species are also good biocontrol bacteria producing various antifungal compounds, such as lipopeptides (Ongena and Jacques, 2008). For many of these organisms, gene clusters encoding biosynthetic pathways have been cloned and characterized (Ehling-Schulz et al., 2005; Loper et al., 2008). Increased efficacy and potential in biological control through engineering of these gene clusters have also been documented (Romero-Tabarez et al., 2006; Rondon et al., 2004).

Bacteria in the Burkholderia cepacia complex possess diverse beneficial properties, such as indole acetic acid production, nitrogen fixation, and antifungal compound production (Parker and Gurian-Sherman, 2001). These organisms can produce a large variety of antifungal compounds, such as cepacidine (Lee et al., 1994), pyrrolnitrin (Jayaswal et al., 1993), xylocandins (Meyers et al., 1987), and siderophores (Sokol et al., 1992). Most recently purified and identified antibiotic from Burkholderia contaminans with antibacterial and antifungal activity was occidiofungin, a unique antifungal glycolipopetide (Gu et al., 2011; Gu et al., 2009; Lu et al., 2009). Discovery of occidiofungin and its biosynthetic gene cluster brought some potential of new antimicrobial compound discovery from Burkholderia species. The B. cepacia complex includes interesting strains for fungal disease management (Santos et al., 2004); however, some strains in the complex are clinical pathogens that cause cystic fibrosis (Holmes et al., 1998). Nevertheless, these strains can be effective biocontrol agents for Pythiuminduced damping-off and Aphanomyces-induced root rot of pea (King and Parke, 1993; Parke et al., 1991), Botrytisinduced gray mold of apple (Janisiewicz and Roitman, 
1988), Sclerotinia sclerotiorum-induced sclerotinia wilt (McLoughlin et al., 1992), and other fungal diseases. Recently, it was reported that accurate investigation of $B$. cepacia complex can discriminate clinical isolates from other beneficial bacteria (Mahenthiralingam et al., 2005). $B$. pyrrocinia $\mathrm{CH}-67$ is a promising biocontrol agent, belonging to the $B$. cepacia complex genomovar IX, which is not associated with clinical isolates (Lee et al., 2011). $B$. pyrrocinia $\mathrm{CH}-67$ exhibited effective disease control activity against tomato leaf mold, and Rhizoctonia-induced damping-off of crisphead lettuce and tomato plants (Lee et al., 2011). So far, a few genetic elements responsible for the antimicrobial and antifungal activities of Burkholderia have been characterized. Strain $\mathrm{CH}-67$ exhibits a diverse range of antifungal activities against plant pathogens and is effective in controlling leaf mold in tomato plants (Lee et al., 2011).

In this study, transposon mutagenesis was used to obtain non-antagonistic mutants and the mutated genes were identified to analyze the antagonistic activity of $B$. pyrrocinia $\mathrm{CH}-67$. The findings from this study provide important information on the gene encoding adenylate kinase which is responsible for antifungal metabolite production in $B$. pyrrocinia.

Table 1. Bacterial strains, plasmids, and primers used in this study

\begin{tabular}{|c|c|c|}
\hline Strain or plasmid & Relevant characteristics & Source or reference \\
\hline \multicolumn{3}{|c|}{ Burkholderia pyrrocinia } \\
\hline CH-67 & Wild-type $B$. pyrrocinia isolate & Lee et al., 2011 \\
\hline M208 & AKÓÓplasposon derivative of $\mathrm{CH}-67 \mathrm{Tp}^{\mathrm{R}}$ & This study \\
\hline \multicolumn{3}{|l|}{ E. coli } \\
\hline DH5 $\alpha$ & endA1 hsdR recA1 gyrA relA $\Phi 80$ lacZ $\Delta \mathrm{M} 15$ & Sambrook et al., 1989 \\
\hline SM10 & RP4-2-Tc::Mu recA thi pro his, $\mathrm{Km}^{\mathrm{R}}$ & Simon et al., 1983 \\
\hline HB101 & recA rpsL ara galK leu hsdS $\Delta$ (gpt-proA) supE xyl & Sambrook et al., 1989 \\
\hline \multicolumn{3}{|l|}{ Plasmids } \\
\hline pTnModOTp' & Self-cloning mini- $\mathrm{Tn} 5$ derivative, $\mathrm{Tp}^{\mathrm{R}}$ & Dennis and Zylstra, 1998 \\
\hline pProTP & $\begin{array}{l}\text { Trimethoprim resistance gene PCR amplified with Trmp Pro and Trmp R } \\
\text { primers and cloned into pGEM-T Easy }\end{array}$ & This study \\
\hline pRK2013 & $\begin{array}{l}\text { RK2 derivative used as helper for conjugations, ColE1 replicon, Tra+-mobi- } \\
\text { lizing plasmid, } \mathrm{Km}^{\mathrm{R}}\end{array}$ & Figurski and Helinski, 1979 \\
\hline pRK415 & IncP1 replicon, $\mathrm{Mob}^{+} \mathrm{Tc}^{\mathrm{R}}$ & Keen et al., 1988 \\
\hline pRC415 & IncP1 replicon, $\mathrm{Mob}^{+} \mathrm{Tc}^{\mathrm{R}}, \mathrm{Cm}^{\mathrm{R}}$ & This study \\
\hline pRAK415 & $\begin{array}{l}\text { Adenylate kinase gene in pAK } 129 \text { digested with HindIII and } X b a \mathrm{I} \text { and } \\
\text { cloned into pRC415 }\end{array}$ & This study \\
\hline pGEM T-Easy & $A m p^{\mathrm{R}}, \mathrm{TA}$ cloning vector & Promega, USA \\
\hline pUC129 & Plasmid cloning vector, $A m p^{R}$ & Keen et al., 1988 \\
\hline pChlo & $\begin{array}{l}\text { Chloramphenicol resistance gene PCR amplified with Chloram F and Chlo- } \\
\text { ram R primers and cloned into pGEM-T Easy }\end{array}$ & This study \\
\hline pProAKR2 & $\begin{array}{l}\text { Adenylate kinase gene PCR amplified with Adenyl F and Adenyl Pro R } \\
\text { primers and cloned into pGEM-T Easy }\end{array}$ & This study \\
\hline pAK129 & $\begin{array}{l}\text { Adenylate kinase gene in pProAKR2 digested with SpeI and SphI and } \\
\text { cloned into pUC129 }\end{array}$ & This study \\
\hline pM208 & $\begin{array}{l}\text { Recombinant plasmid carrying the transposon and flanking sequences of } \\
\text { M208; this plasmid was obtained by self-ligation of a Pstl-digested frag- } \\
\text { ment of M208 }\end{array}$ & This study \\
\hline \multicolumn{3}{|c|}{ Oligonucleotides sequence (5' to $\left.3^{\prime}\right)$} \\
\hline Adenyl Pro F & TCG TGA CGC GCG CCT GAT GGT G & \\
\hline Adenyl R & TCA GCC GTT GGC GCG AGC GTG CAT CT & \\
\hline Chloram F & ACC AAT AAC TGC CTT AA & \\
\hline Chloram R & GAG CTT ATC GCG AAT AAA T & \\
\hline PPI MB ori & TTT TGC TCA CAT GTT CTT TCC TG & \\
\hline Trmp F & ATG GGT CAA AGT AGC GAT GAA GCC & \\
\hline Trmp Pro & GCC TGT TCG GTT CGT AAA CTG & \\
\hline Trmp R & ATT CTT AGG CCA CAC GTT CAA & \\
\hline
\end{tabular}




\section{Materials and Methods}

Culture conditions and media. The bacterial strains and plasmids used in this study are listed in Table 1 . Nutrient broth (NB) was used to culture Burkholderia strains at $30^{\circ} \mathrm{C}$. Escherichia coli cultures were routinely grown at $37^{\circ} \mathrm{C}$ in Luria-Bertani (LB) medium (Sambrook et al., 1989). The fungal pathogen Fulvia fulva TF-13 was cultured at $25^{\circ} \mathrm{C}$ on potato dextrose agar (PDA) plates. The following antibiotic concentrations were used for E. coli and Burkholderia strains: ampicillin, $100 \mu \mathrm{g} / \mathrm{ml}$; kanamycin, $50 \mu \mathrm{g} / \mathrm{ml}$; chloramphenicol, $25 \mu \mathrm{g} / \mathrm{ml}$; and trimethoprim, $50 \mu \mathrm{g} / \mathrm{ml}$. To isolate antifungal activity-deficient mutants of Burkholderia, PDA was used for plate bioassays.

Transposon mutagenesis and selection of antifungal activity-deficient mutants. Transposon mutagenesis of $B$. pyrrocinia $\mathrm{CH}-67$ was performed using the mini-Tn5 derivative plasposon in pTnMod-OTp (Dennis and Zylstra, 1998) to select mutants with altered antifungal activity. Transposon-inserted mutants were selected by plating the exconjugants of $\mathrm{CH}-67$ on $\mathrm{M} 9$ minimal agar containing 50 $\mu \mathrm{g} / \mathrm{ml}$ trimethoprim. The resulting trimethoprim-resistant colonies were picked and inoculated in NB containing 50 $\mu \mathrm{g} / \mathrm{ml}$ trimethoprim. To select mutants deficient in antifungal activity (non-antagonistic mutants), F. fulva spore solution was prepared and spread on PDA plates, and the mutant bacterial suspension was simply dropped on the PDA plate and incubated for $3-5$ days at $25^{\circ} \mathrm{C}$ (Fig. 1). The fungal spore suspension $\left(1 \times 10^{5}\right.$ conidia/ml $)$ was prepared in sterile water from fungal cultures grown on PDA. To prepare the fungal spore suspension, $F$. fulva TF-13 was inoculated on PDA and incubated for 2 weeks at $25^{\circ} \mathrm{C}$.

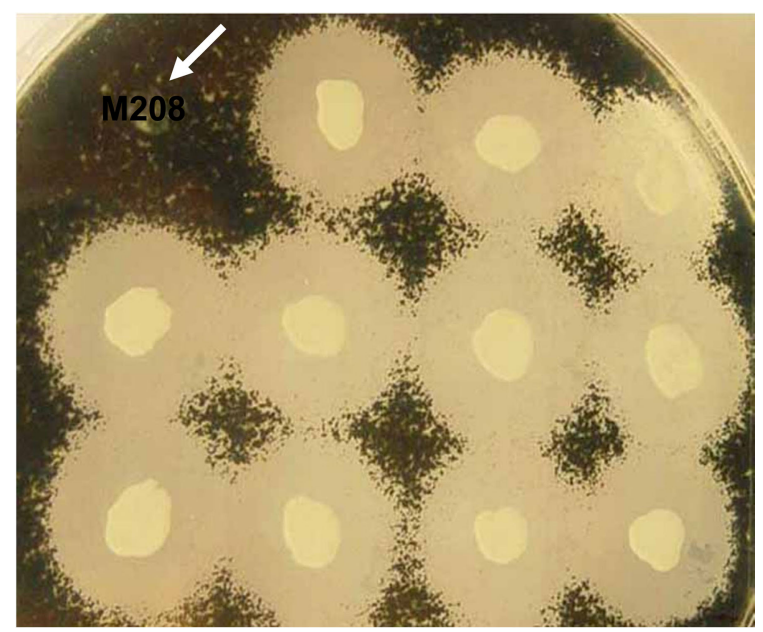

Fig. 1. Selection of a non-antagonistic mutant from a library of Burkholderia pyrrocinia CH-67 mutants using Fulvia fulva spores. One mutant (indicated by white arrow) did not exhibit antifungal activity.
Four grown fungal discs $(\varnothing=1 \mathrm{~cm})$ were plated to $100 \mathrm{ml}$ of PD broth, and the inoculum was incubated for 4 days at $25{ }^{\circ} \mathrm{C}$ and $150 \mathrm{rpm}$. The culture broth was filtered through a double-layer of sterile cheesecloth to remove mycelial fragments. The conidial suspension was diluted in PD broth until $\mathrm{A}_{550}=0.4$.

Bacterial mutants showing either no inhibition of fungal mycelium growth or reduced fungal growth were selected and stored at $-80^{\circ} \mathrm{C}$ until use. Following the selection of mutants lacking antifungal activity, transposon insertion was examined using Southern hybridization. Genomic DNA from wild-type and mutant $B$. pyrrocinia was purified using Genomic DNA extraction kit (Cosmo, Korea), digested overnight with the appropriate restriction enzymes, fractionated on a $0.8 \%$ agarose gel, and transferred to Hybond$\mathrm{N}+$ nylon membrane (Amersham Pharmacia Biotech., Piscataway, USA) by Southern blotting (Sambrook et al., 1989). Hybridization and detection were carried out under normal-stringency conditions using a probe DNA labeled with DIG DNA labeling and Detection Kit (Roche, Germany). The trimethoprim resistance gene (dhfr) from pTnModOTp' and a putative adenylate kinase gene were used as probes.

Gene cloning and DNA sequencing. General DNA manipulations were performed as described by Sambrook et al. (Sambrook et al., 1989). To identify the transposon-inserted site in the CH-67 mutants, chromosomal DNA containing the transposon insertion was isolated to rescue the plasmid carrying the transposon-inserted DNA. Briefly, PstI-digested chromosomal DNA of the mutant M208, which was deficient in antifungal activity, was self-ligated with T4 DNA ligase and subsequently used to transform $E$. coli DH5 $\alpha$. Plasmid DNA was isolated from the resulting transformants, digested with PstI and analyzed by agarose gel electrophoresis. Plasmid DNAs were also used as templates in sequencing reactions with the primers PPI MB ori and Trmp F (Table 1).

Primers for the putative adenylate kinase gene were designed based on the genomic DNA sequences flanking the transposon insertion site in the mutant M208. The adenylate kinase gene was amplified using the adenyl Pro F and adenyl $\mathrm{R}$ primers (Table 1). The PCR products were amplified from CH-67 chromosomal DNA using LA Taq DNA polymerase (Takara, Japan).

Complementation analysis of M208. Because $B$. pyrrocinia $\mathrm{CH}-67$ was resistant to several antibiotics, it was impossible to use many of broad host range shuttle plasmids to complement the mutant M208 using original adenylate kinase gene. Therefore, we first constructed a modified broad host range plasmid using pRK415, which carries the chloramphenicol acetyltransferase gene (cat), for mutant comple- 
mentation. Chloramphenicol is an effective antibiotic for the CH-67 strain, thereby making cat an effective selection marker. The chloramphenicol resistance gene, cat, was amplified from the fosmid pEPI-FOS5 (Epicentre, Madison, USA) using the primers Chloram F and Chloram R (Table 1) and cloned into StuI-digested pRK415 to create pRC415 (Table 1). The DNA fragment containing the intact adenylate kinase gene was amplified from $B$. pyrrocinia $\mathrm{CH}-67$ genomic DNA using the primers Adenyl Pro F and Adenyl $\mathrm{R}$. The $811 \mathrm{bp}$ amplified DNA included the promoter area and full coding region of the adenylate kinase gene, and was cloned into pGEM-T Easy (Promega, Madison, USA) to create pProAKR2. The $0.8 \mathrm{~kb} S p h \mathrm{I}$ and $S p e \mathrm{I}$ fragment of pProAKR2 was cloned into pUC129 to generate pAK129. Plasmid pAK129 was digested with HindIII and $X b a \mathrm{I}$, and the full-length gene encoding adenylate kinase was cloned into pRC415 to create pRAK415. The complementation plasmid pRAK415 was first transformed into $E$. coli SM10 for subsequent transfer to the mutant M208 using a biparental mating procedure (Simon et al., 1983). The empty vector (pRC415) was used as a control. M208 conjugants carrying pRAK415 were selected on M9 minimal medium containing trimethoprim and chloramphenicol. Complementation experiments were conducted using plate assays to evaluate antifungal activity against $F$. fulva.

Nucleotide sequence accession numbers. The nucleotide sequences of the pProAKR2 inserts have been deposited in GenBank under the accession numbers JQ929304.

\section{Results}

Selection of non-antagonistic mutants. A total of 2,500 transposon-insertion mutants were screened using $F$. fulva to select mutants deficient in antifungal activity (Fig. 1). A mutant, M208, deficient in antifungal activity against $F$. fulva was selected, while the mutant was not an auxotroph. Many of mutants showing either deficiency of antifungal activity or reduced antifungal activity appeared to be auxotrophic mutants, because they were not grown on a minimal medium M9. Growth of M208 was somewhat slower compared to that of the wild type; however, the wild-type and mutant cell numbers were not different after 48-h incubation in liquid culture such as NB (Fig. 2). Southern blot analysis of Pst I, EcoRI-digested genomic DNA of the mutant revealed a clear single hybridization signal (data not shown). This result indicated that the transposon was inserted into the mutant chromosome as a single copy, suggesting that the disrupted gene may be responsible for the antifungal activity-deficient phenotype of the selected mutant.

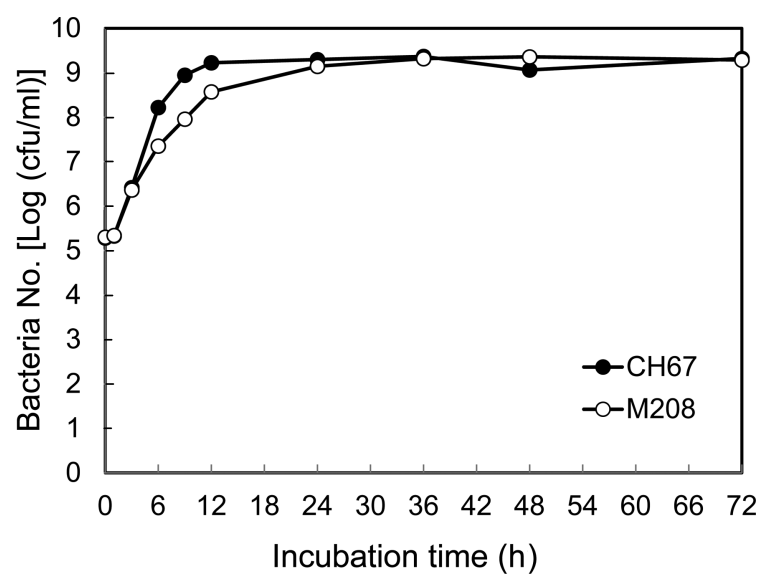

Fig. 2. Bacterial growth curve based on viable cell count in nutrient broth by 10 -fold dilution plating.

Identification of the transposon insertion site. Mutated genes in the M208 mutant were identified with a plasmid rescue approach using self-ligated chromosomal DNA. The plasmid pM208 was obtained from the genome of M208 using a conventional plasmid rescue method. The plasmid pM208 carried a 1.8-kb genomic DNA insert from the mutant (data not shown). The transposon-inserted region was determined by inverse PCR sequencing with the primers PPI MB ori and Trmp F using the recombinant plasmid pM208. The DNA sequences of the rescued plasmids were similar to that of genes from some Burkholderia species. The disrupted gene in M208 was similar to a gene encoding a putative adenylate kinase in $B$. cenocepacia $\mathrm{MCO}-3$. The full-length gene for adenylate kinase was obtained by PCR from the wild-type CH-67 strain and DNA sequences of the adenylate kinase gene were determined. The deduced amino acid sequence of adenylate kinase from $\mathrm{CH}-67$ was $80 \%$ identical to that from the MCO-3 strain. The gene organization flanking the adenylate kinase gene in MCO-3 indicated that the mutated gene may not be linked with other genes as an operon (data not shown). Multiple alignment of adenylate kinase from $\mathrm{CH}-67$ and other bacteria revealed that the N-terminal region of the protein was conserved among the homologs (Fig. 3).

Adenylate kinase for antifungal compound production. To determine the function of adenylate kinase in B. pyrrocinia $\mathrm{CH}-67$, adenosine monophosphate (AMP), adenosine triphosphate (ATP), or adenosine diphosphate (ADP) was added to the M208 culture broth and antifungal activity was examined. Addition of AMP or ATP alone did not restore antifungal activity in the M208 mutant (Table 2). However, the antifungal activity of M208 was restored when AMP and ATP were added together in the bacterial cultures. Addition of ADP (1 mM to $20 \mathrm{mM}$ ) to the M208 culture 

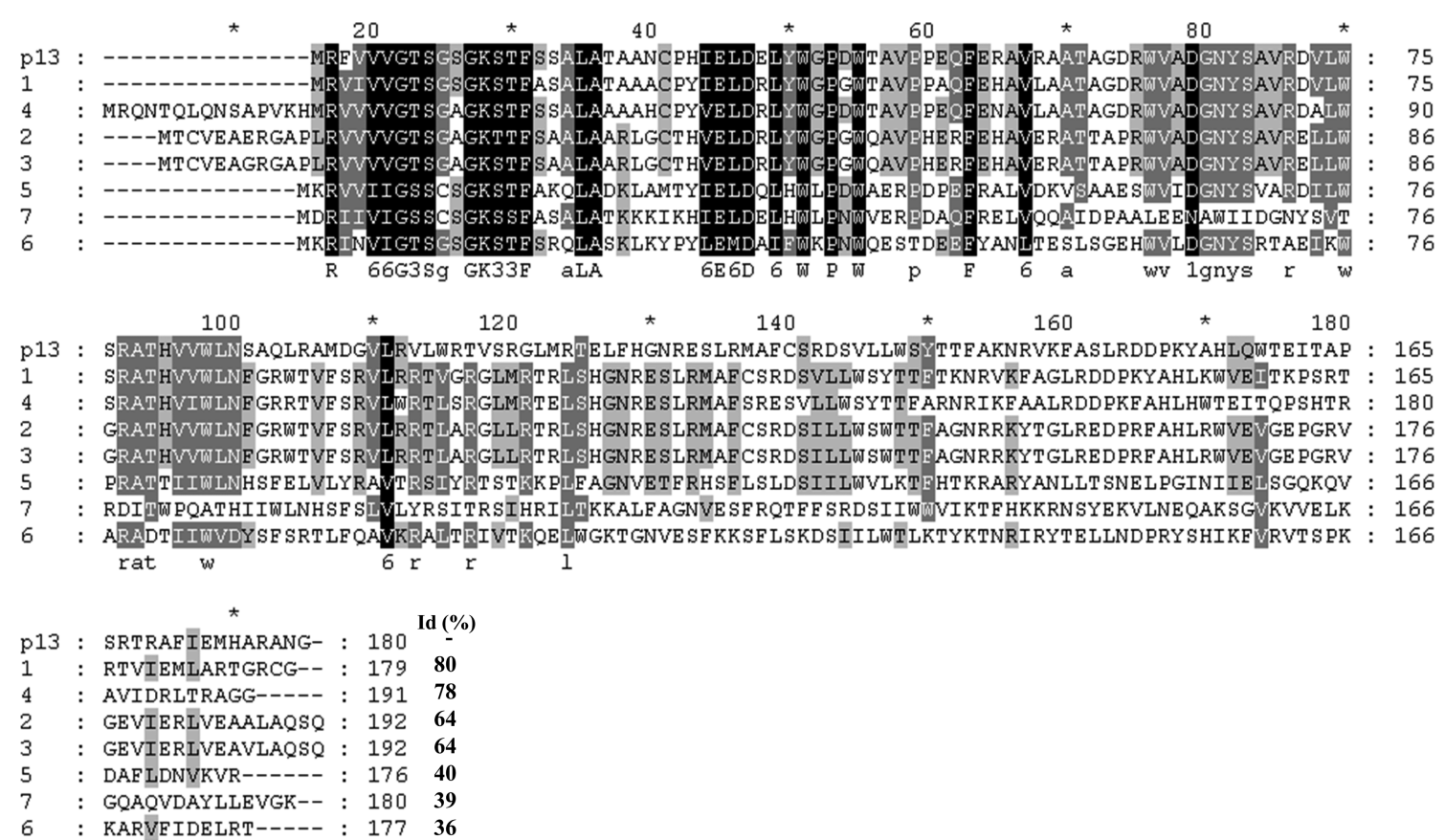

Fig. 3. Multiple alignment of adenylate kinase (p13) from B. pyrrocinia $\mathrm{CH}-67$ with those from other bacteria. p13, B. pyrrocinia CH-67; 1, B. cenocepacia MCO-3 (YP_001773957); 2, Pseudomonas aeruginosa 2192 (ZP_00971614); 3, P. aeruginosa UCBPP-PA14 (YP_793262); 4, Burkholderia sp. 383 (YP_366854,); 5, Shewanella woodyi ATCC 51908 (YP_001760355); 6, Vibrio vulnificus CMC̄P6 (NP_761309); 7, Marinomonas sp. MED121 (ZP_01078528).

Table 2. Adenine nucleotide concentrations used to restore antifungal activity in M208

\begin{tabular}{|c|c|c|}
\hline No. & Treatment & $\begin{array}{l}\text { Antifungal } \\
\text { activity }^{\mathrm{a}}\end{array}$ \\
\hline 1 & M208 + 1 mM ATP & - \\
\hline 2 & $\mathrm{M} 208+10 \mathrm{mM}$ ATP & - \\
\hline 3 & $\mathrm{M} 208+20 \mathrm{mM}$ ATP & - \\
\hline 4 & M208 + 1 mM AMP & - \\
\hline 5 & M208 + 10 mM AMP & - \\
\hline 6 & $\mathrm{M} 208+20 \mathrm{mM}$ AMP & - \\
\hline 8 & M208 + 1 mM ADP & + \\
\hline 9 & $\mathrm{M} 208+10 \mathrm{mM}$ ADP & + \\
\hline 10 & $\mathrm{M} 208+20 \mathrm{mM}$ ADP & + \\
\hline 11 & M208 + 1 mM ATP + 1 mM AMP & - \\
\hline 12 & $\mathrm{M} 208+10 \mathrm{mM}$ ATP $+10 \mathrm{mM}$ AMP & + \\
\hline 13 & $\mathrm{M} 208+20 \mathrm{mM}$ ATP $+20 \mathrm{mM}$ AMP & + \\
\hline 15 & B. pyrrocinia $\mathrm{CH}-67$ & ++ \\
\hline 16 & M208 & - \\
\hline
\end{tabular}

${ }^{\mathrm{a}}$ Inhibition zone assay was performed twice. Zone of inhibition:,- 0 $\mathrm{mm} ;+, 1-5 \mathrm{~mm} ;++,>5 \mathrm{~mm}$.

broth also restored antifungal activity (Table 2). The adenylate kinase gene disrupted in the transposon mutant M208 was complemented to confirm the role of the adenylate kinase gene in antifungal metabolite production. The plasmid pRAK415, carrying the wild-type adenylate kinase gene,

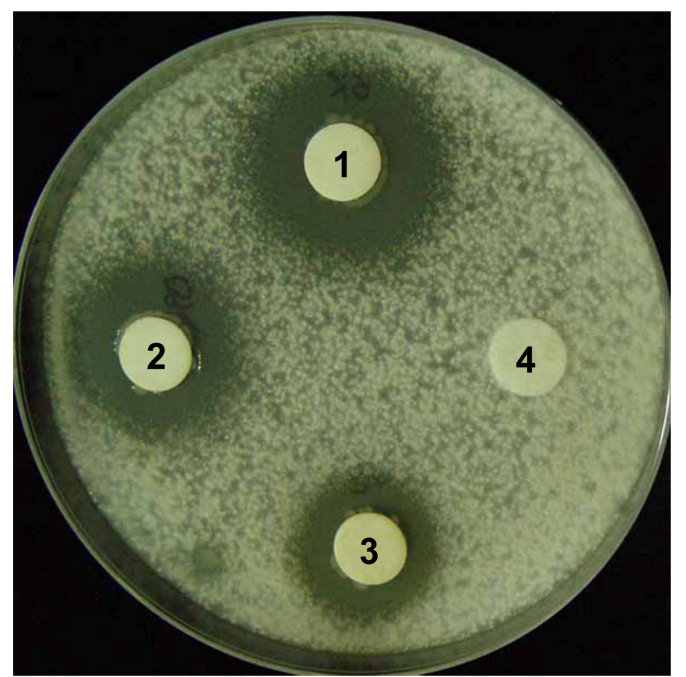

Fig. 4. Recovery of antifungal activity in the mutant M208 complemented in trans with the full-length adenylate kinase gene. 1, B. pyrrocinia $\mathrm{CH}-67$ containing pRC415; 2, B. pyrrocinia M208 containing pRAK415-9; 3, B. pyrrocinia M208 containing pRAK415-21; 4, B. pyrrocinia M208 containing pRC415.

was introduced into the mutant M208 in trans. Mutant M208 carrying pRAK415 inhibited the growth of F. fulva as efficiently as the wild-type strain (Fig. 4). In contrast, mutant M208 harboring the empty vector pRC415 was deficient in antifungal activity. Moreover, pRC415 did not 
affect antifungal activity when introduced into wild-type CH-67 (Fig. 4). Our results suggest that adenylate kinase may be involved in antifungal activity expression in $\mathrm{CH}-67$.

\section{Discussion}

Burkholderia cepacia complex (Bcc), firstly reported as a plant pathogen responsible for a bacterial rot of onions (Burkholder, 1950), and recently it has been warned that some strains of Bcc can causes cystic fibrosis in human, and thus some Bcc considered as clinical strains. However, some soil strains in the Bcc complex have been recognized as an effective biocontrol agent and biotechnological use (Chiarini et al., 2006). An antagonistic bacterium B. pyrrocinia $\mathrm{CH}-67$ with strong antifungal activity against many plant pathogenic fungi was previously isolated from forest soil (Lee et al., 2011). The CH-67 strain demonstrated to belong to genomovar IX and identified as B. pyrroconia. The genomovar IX is known to be the representative genomovar containing mostly non-clinical strains of Bcc (Mahenthiralingam et al., 2005).

To understand the molecular mechanisms underlying the antagonistic activity of $B$. pyrrocinia $\mathrm{CH}-67$, mutagenesis and subsequent identification of the gene responsible for antifungal activity were carried out. A total of 2,500 mutants were screened using a fungal spore-based method to select non-antagonistic mutants. This method is rapid and useful to select antifungal activity-deficient mutants in a short time. The gene responsible for the antifungal activity was identified using a plasmid-rescue approach with the selected mutant. Many studies have combined transposon mutagenesis with flanking DNA sequencing of insertion sites (Hoffman et al., 2000; Horecka and Jigami, 2000; Lee et al., 2003; Ruffin et al., 2000). This study selected only one mutant defective in antifungal activity. However, only 2,500 mutants were screened and it may be possible that more non-antagonistic mutants could be obtained by screening more mutants.

Here, a gene encoding adenylate kinase, which is associated with antifungal activity in B. pyrrocinia $\mathrm{CH}-67$, was identified using the M208 mutant. Adenylate kinase plays a key role in the interconversion of the constituents of the adenine nucleoside pool, catalyzing the reversible reaction ATP + AMP to ADP (Glaser et al., 1975). Regulation of adenylate kinase activity may provide the cell with a mechanism for controlling macromolecular biosynthesis such as membrane phospholipids and regulating cell growth (Goelz and Cronan, 1982; Huss and Glaser, 1983). The adenylate kinase gene in this study may be involved in regulating the expression of antifungal activity. In the ATP/ ADP/AMP feeding experiment, ADP was able to restore antifungal activity in the M208 mutant, suggesting that the gene identified in this study was truly functioning as adenylate kinase and that the ATP/ADP/AMP balance may be essential for antifungal compound production. In $B$. pyrrocinia $\mathrm{CH}-67$, adenylate kinase may control the expression of antifungal activity and may partially regulate bacterial growth rate. Inactivation of adenylate kinase (as in M208) caused a delay in initial bacterial growth. This may be due to the ATP/ADP/AMP imbalance in the adenylate kinase mutant. However, the wild-type and M208 cell numbers were not different after 48-h incubation, indicating that the antifungal activity deficiency in M208 was not due to delayed bacterial growth. The M208 mutant did not exhibit antifungal activity even after 72-h incubation. Addition of ADP or high concentrations of ATP and AMP together restored the bacterial growth rate and antifungal activity in M208, suggesting the importance of adenylate kinase in CH-67.

While many studies on adenylate kinase are mainly focused on its role in nucleotide mechanism, there are several reports on other alteration of bacterial phenotypes by inactivation of adenylate kinase other than nucleotide metabolism. Adenylate kinase has been extensively studied in $E$. coli and is involved in macromolecule biosynthesis and cell growth regulation (Goelz and Cronan, 1982). It has been speculated that inactivation of adenylate kinase caused changes in the concentration of adenine nucleotides which in turn caused a defect in some macromolecular synthesis in E. coli (Goelz and Cronan, 1982). In addition, adenlyate kinase in Yersinia pestis is involved in bacterial virulence and nucleotide metabolism since inactivation of adenylate kinase in $Y$. pestis was avirulent (Munier-Lehmann et al., 2003). It is likely that nucleotide imbalance caused by adenylate kinase mutation may be responsible for many bacterial phenotypic alterations.

Introduction of the full-length adenylate kinase gene in trans in M208 completely restored the antifungal activity and initial growth rate to wild-type levels, suggesting that adenylate kinase is involved in antifungal compound production in B. pyrrocinia CH-67. However, it is not clear whether adenylate kinase directly affects antifungal compound production. Our previous attempt to fractionate the antifungal compound from $\mathrm{CH}-67$ culture supernatant was unsuccessful because of poor solubility of the antifungal compound in organic solvents. Therefore, the nature of the antifungal compounds produced by the $\mathrm{CH}-67$ strain remains unknown. The nucleotide imbalance in the mutant M208 may have caused an imbalance in bacterial metabolism, resulting in a dramatic reduction in the production of bacterial secondary metabolite that may possess antifungal activity. The mechanisms underlying the involvement of adenylate kinase in antifungal activity expression in $B$. pyrrocinia $\mathrm{CH}-67$ should be further investigated. To our 
best knowledge, this is the first study to show that adenylate kinase is involved in antifungal activity expression in a biocontrol bacterium such as $B$. pyrrocinia.

\section{Acknowledgments}

This study was supported by a grant from the NextGeneration BioGreen 21 Program (No. PJ008201), Rural Development Administration and by a grant (Project No. 60900251) from the Screening Center for Disease Resistant Vegetable Crops of TDPAF funded by MIFAFF, Republic of Korea.

\section{References}

Andrews, J. H. 1992. Biological control in the phyllosphere. Annu. Rev. Phytopathol. 30:603-635.

Asaka, O. and Shoda, M. 1996. Biocontrol of Rhizoctonia solani damping-off of tomato with Bacillus subtilis RB14. Appl. Environ. Microbiol. 62:4081-4085.

Becker, J. O. and Schwinn, F. J. 1993. Control of soil-borne pathogens with living bacteria and fungi: status and outlook. Pestic. Sci. 37:355-363.

Burkholder, W. H. 1950. Sour skin, a bacterial rot of onion bulbs. Phytopathology 40:115-118.

Chiarini, L., Bevivino, A., Dalmastri, C., Tabacchioni, S. and Visca, P. 2006. Burkholderia cepacia complex species: health hazards and biotechnological potential. Trends Microbiol. $14: 277-286$.

Dennis, J. J. and Zylstra, G. J. 1998. Plasposons: modular selfcloning mini-transposon derivatives for the rapid genetic analysis of gram-negative bacterial genomes. Appl. Environ. Microbiol. 64:2710-2715.

Dowling, D. N. and O'Gara, F. 1994. Metabolites of Pseudomonas involved in the biocontrol of plant disease. Trends Biotechnol. 12:133-141.

Ehling-Schulz, M., Vukov, N., Schulz, A., Shaheen, R., Andersson, M., Martlbauer, E. and Scherer, S. 2005. Identification and partial characterization of the nonribosomal peptide synthetase gene responsible for cereulide production in emetic Bacillus cereus. Appl. Environ. Microbiol. 71:105-113.

El-Banna, N. and Winkelmann, G. 1998. Pyrrolnitrin from Burkholderia cepacia: antibiotic activity against fungi and novel activities against Streptomyces. J. Appl. Microbiol. 85:69-78.

Farr, D. F., Bills, G. F., Chamuris, G. P. and Rossman, A. Y. 1989. Fungi on Plants and Plant Products in the United States. American Phytopathological Society, St. Paul, Minn, USA

Fenton, A. M., Stephens, P. M., Crowley, J., O'Callaghan, M. and O'Gara, F. 1992. Exploitation of gene(s) involved in 2,4diacetylphloroglucinol biosynthesis to confer a new biocontrol capability to a Pseudomonas strain. Appl. Environ. Microbiol. 58:3873-3878.

Figurski, D. H. and Helinski, D. R. 1979. Replication of an origin containing derivative of plasmid RK2 dependent on a plasmid function provided in trans. Proc. Natl. Acad. Sci. USA 76:1648-1652.

Glaser, M., Nulty, W. and Vagelos, P. R. 1975. Role of adenylate kinase in the regulation of macromolecular biosynthesis in a putative mutant of Escherichia coli defective in membrane phospholipid biosynthesis. J. Bacteriol. 123:128-136.

Goelz, S. E. and Cronan, J. E. Jr. 1982. Adenylate kinase of Escherichia coli: evidence for a functional interaction in phospholipid synthesis. Biochemistry 21:189-195.

Gu, G., Smith, L., Wang, N., Wang, H. and Lu, S.-E. 2009. Biosynthesis of an antifungal oligopeptide in Burkholderia contaminans strain MS14. Biochem. Biophys. Res. Commun. 380:328-332.

Gu, G., Smith, L., Liu, A. and Lu, S.-E. 2011. Genetic and biochemical map for the biosynthesis of occidiofungin, an antifungal produced by Burkholderia contaminans strain MS14. Appl. Environ. Microbiol. 77:6189-6198.

Handelsman, J. and Stabb, E. V. 1996. Biocontrol of soilborn plant pathogens. Plant Cell 8:1855-1869.

Hill, D. S., Stein, J. I., Torkewitz, N. R., Morse, A. M., Howell, C. R., Pachlatko, J. P., Becker, J. O. and Ligon, J. M. 1994. Cloning of genes involved in the synthesis of pyrrolnitrin from Pseudomonas fluorescens and role of pyrrolnitrin synthesis in biological control of plant disease. Appl. Environ. Microbiol. 60:78-85.

Hoffman, L. M., Jendrisak, J. J., Meis, R. J., Goryshin, I. Y. and Reznikof, S. W. 2000. Transposome insertional mutagenesis and direct sequencing of microbial genomes. Genetica. 108:19-24.

Holmes, A., Govan, J. and Goldstein, R. 1998. Agricultural use of Burkholderia (Pseudomonas) cepacia: a threat to human health? Emerg. Infect. Dis. 4:221-227.

Horecka, J. and Jigami, Y. 2000. Identifying tagged transposon insertion sites in yeast by direct genomic sequencing. Yeast 16:967-970.

Howell, C. R. and Stipanovic, R. D. 1980. Suppression of Pythium ultimum induced damping-off of cotton seedlings by Pseudomonas fluorescens and its antibiotic pyoluteorin. Phytopathology 70:712-715.

Huss, R. J. and Glaser, M. 1983. Identification and purification of an adenylate kinase-associated protein that influences the thermolability of adenylate kinase from a temperature-sensitive adk mutant of Escherichia coli. J. Biol. Chem. 258:1337013376.

Janisiewicz, W. J. and Roitman, J. 1988. Biological control of blue mold and gray mold on apple and pear with Pseudomonas cepacia. Phytopathology 78:1697-1700.

Jayaswal, R. K., Fernandez, M., Upadhyay, R. S., Visintin, L., Kurz, M., Webb, J. and Rinehart, K. 1993. Antagonism of Pseudomonas cepacia against phytopathogenic fungi. Curr. Microbiol. 26:17-22.

Keel, C., Schnider, U., Maurhofer, M., Voisard, C., Laville, J., Burger, U., Wirthner, P., Haas, D. and Défago, G. 1992. Suppression of root diseases by Pseudomonas fluorescens CHA0: importance of the bacterial secondary metabolite 2,4-diacetylphloroglucinol. Mol. Plant-Microbe Interact. 5:4-13. 
Keen, N. T., Tamaki, S., Kobayashi, D. and Trollinger, D. 1988. Improved broad-host-range plasmids for DNA cloning in gram-negative bacteria. Gene 70:191-197.

King, E. B. and Parke, J. L. 1993. Biocontrol of Aphanomyces root rot and Pythium damping-off by Pseudomonas cepacia AMMD on four pea cultivars. Plant Dis. 77:1185-1188.

Kraus, J. and Loper, J. E. 1995. Characterization of a genomic region required for production of the antibiotic pyoluteorin by the biological control agent Pseudomonas fluorescens Pf-5. Appl. Environ. Microbiol. 61:849-854.

Lee, C. H., Kim, S., Hyun, B., Suh, J. W., Yon, C., Kim, C., Lim, Y. and Kim, C. 1994. Cepacidine A, a novel antifungal antibiotic produced by Pseudomonas cepacia. J. Antibiot. 47:14021418.

Lee, H., Vazquez-Laslop, N., Klyachko, K. A. and Neyfakh, A. A. 2003. Isolation of antibiotic hyper susceptibility mutants of Acinetobacter spp. by selection for DNA release. Antimicrob. Agents Chemother. 47:1267-1274.

Lee, K. Y., Kong, H. G., Choi, K. H., Lee, S.-W. and Moon, B. J. 2011. Isolation and identification of Burkholderia pyrrocinia CH-67 to control tomato leaf mold and damping-off on crisphead lettuce and tomato. Plant Pathology J. 27:59-67.

Loper, J. E., Henkels, M. D., Shaffer, B. T., Valeriote, F. A. and Gross, H. 2008. Isolation and identification of rhizoxin analogs from Pseudomonas fluorescens Pf-5 by using a genomic mining strategy. Appl. Environ. Microbiol. 74:3085-3093.

Lu, S.-E., Noval, J., Austin, F. W., Gu, G., Ellis, D., Kirk, M., Wilson-Stanford, S., Tonelli, M. and Smith, L. 2009. Occidiofungin, a unique antifungal glycopeptides produced by a strain of Burkholderia contaminans. Biochemistry 48:8312-8321.

Mahenthiralingam, E., Urban, T. A. and Goldberg, J. B. 2005. The multifarious, multireplicon Burkholderia cepacia complex. Nat. Rev. Microbiol. 3:144-156.

Mao, W., Lumsden, R. D., Lewis, J. A. and Hebbar, P. K. 1998. Seed treatment using pre-infiltration and biocontrol agents to reduce damping-off of corn caused by species of Pythium and Fusarium. Plant Dis. 82:294-299.

Mavrodi, D. V., Blankenfeldt, W. and Thomashow, L. S. 2006. Phenazine compounds in fluorescent Pseudomonas spp. biosynthesis and regulation. Annu. Rev. Phytopathol. 44:417-445.

McLoughlin, T. J., Quinn, J. P., Bettermann, A. and Bookland, R. 1992. Pseudomonas cepacia suppression of sunflower wilt fungus and role of antifungal compounds in controlling the disease. Appl. Environ. Microbiol. 58:1760-1763.

Meyers, E., Bisacchi, G. S., Dean, L., Liu, W. C., Minassian, B., Slusarchyk, D. S., Sykes, R. B., Tanaka, S. K. and Trejo, W. 1987. Xylocandin: a new complex of antifungal peptides. I. Taxonomy, isolation and biological activity. J. Antibiot. 40: $1515-1519$.

Munier-Lehmann, H., Chenal-Francisque, V., Ionescu, M., Chrisova, P., Foulon, J., Carniel, E. and Bârzu, O. 2003. Relation- ship between bacterial virulence and nucleotide metabolism: a mutation in the adenylate kinase gene renders Yersinia pestis avirulent. Biochem. J. 373:515-522.

Ongena, M. and Jacques, P. 2008. Bacillus lipopeptides: versatile weapons for plant disease control. Trends Microbiol. 16:115125.

Parke, J. L., Rand, R. E., Joy, A. E. and King, E. B. 1991. Biological control of Pythium-damping off and Aphanomyces root rot of peas by application of Pseudomonas cepacia or Pseudomonas fluorescens to seed. Plant Dis. 75:987-992.

Parker, J. L. and Gurian-Sherman, D. 2001. Diversity of the Burkholderia cepacia complex and implications for risk assessment of biological control strains. Annu. Rev. Phytopathol. 39:225-258.

Roberts, D. P., Lohrke, S. M., Meyer, S. L. F., Buyer, J. S., Bowers, J. H., Baker, C. J., Li, W., De Souza, J. T., Lewis, J. A. and Chung, S. 2005. Biocontrol agents applied individually and in combination for suppression of soilborn diseases of cucumber. Crop Prot. 24:141-155.

Romero-Tabarez, M., Jansen, R., Sylla, M., Luensdorf, H., Huessler, S., Santosa, D. A., Timmis, K. N. and Molinari, G. 2006. 7-O-Malonyl macrolactin A, a new macrolactin antibiotic from Bacillus subtilis active against methicillin-resistant Staphylococcus aureus, vancomycin-resistant Enterococci and a small-colony variant of Burkholderia cepacia. Antimicrob. Agents Chemother. 50:1701-1709.

Rondon, M. R., Ballering, K. S. and Thomas, M. G. 2004. Identification and analysis of a siderophore biosynthetic gene cluster from Agrobacterium tumefaciens C58. Microbiology 150: 3857-3866.

Ruffin, D. C., Van Santen, V. L., Zhang, Y., Voelker, L. L., Panangala, V. S. and Dybvig, K. 2000. Transposon mutagenesis of Mycoplasma gallisepticum by conjugation with Enterococcus faecalis and determination of insertion site by direct genomic sequencing. Plasmid 44:191-195.

Sambrook, J., Fritsch, E. F. and Maniatis, T. 1989. Molecular cloning; a laboratory manual, 3rd ed. Cold Spring Harbor Laboratory Press, Cold Spring Harbor, NY, USA.

Santos, A. V., Dillon, R. J., Dillon, V. M., Reynolds, S. E. and Samuels, R. I. 2004. Ocurrence of the antibiotic producing bacterium Burkholderia sp. in colonies of the leaf-cutting ant Atta sexdens rubropilosa. FEMS Microbiol. Lett. 239:319323.

Simon, R., Priefer, U. and Pühler, A. 1983. A broad host range mobilization system for in vivo genetic engineering: transposon mutagenesis in Gram-negative bacteria. Bio/Technology 1:784-795.

Sokol, P. A., Lewis, C. J. and Dennis, J. J. 1992. Isolation of a novel siderophore from Pseudomonas cepacia. J. Med. Microbiol. 36:184-189. 